columns

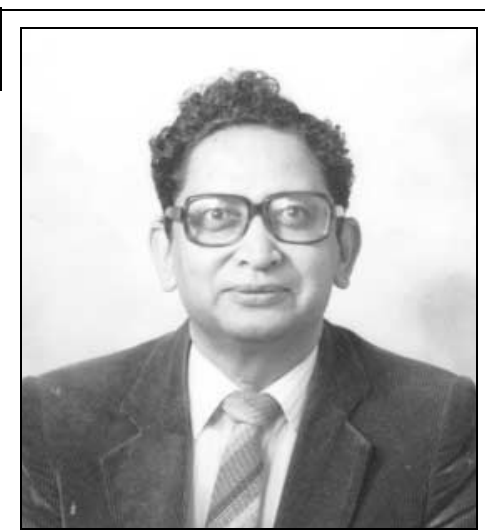

\section{Kunal Raychaudhuri}

\section{Formerly Consultant Psychiatrist, Hollymoor Hospital, Birmingham}

Kunal Raychaudhuri died, aged 74, on 9 January 2003. Born in 1928 in Berhampur, India, Kunal was proud to belong to the land of his birth, but equally proud to have acquired British citizenship after being long domiciled in the UK.

He studied at Calcutta University, where he took his MSc and later, in 1955 , his MB BS. After working in house jobs, he joined the Indian Army in 1957 on a shortterm commission. On completing his army service in 1960, he came to the UK and for the next 3 years worked as a senior house officer and registrar in psychiatry at Cefn Coed Hospital in Swansea. He then took up an appointment as psychiatric registrar at Leverndale Hospital, Glasgow where he worked until 1966. Having obtained the DPM qualification, he moved on to Glenside Hospital in Bristol as Medical Assistant. There he came under the potent influence of Donald Early and his pioneering work in rehabilitation psychiatry, and established himself as a valued member of the Glenside team.

In 1972, Kunal was appointed Consultant Psychiatrist with a special interest in rehabilitation and community care at Hollymoor Hospital, Birmingham. This was one of the earliest specialist posts of its kind established in the West Midlands. In the course of the next few years, he applied the Bristol template with great vigour and determination to the hospital's long-stay population and to the building of a supportive community network to enable resettlement. Truly, his was a pioneering role in the evolution of rehabilitation psychiatry in the West Midlands. In addition to his main field of endeavour, he took a full share in the acute service and was an active participant in the decisionmaking bodies of the hospital and of the hospital group that managed it. Kunal was popular with his colleagues, who held him in much affection for his engaging personal qualities, his readiness to bear his full share of the burden and heat of the day, and his wholehearted commitment to the aims and purposes of the team. His patients liked and respected him, knowing that he would do his best for them. He retired from the Health Service in 1988.

A strong and active supporter of the Royal College of Psychiatrists, he served the College well, and during the last decade of his working life was Secretary of the West Midlands Division, a Member of Council, and a Member of the Public Policy Committee and of the Programmes and Meetings Committee. He was elected to Fellowship in 1987. He was active too in the Overseas Doctors Association and was honoured to take on the responsibility of being its Welfare Officer.

A man who loved life and lived it to the full, he was deeply engaged with his work and with his leisure pursuits. A fine cook, he much enjoyed and was knowledgeable about food. He took great pleasure from periodic visits to the West End theatres, was a keen student of the turf and relished a modest flutter. In his youth, Kunal had been a talented cricketer, wicket-keeper and captain of the cricket team at his medical college, and he retained a lifelong love of the great game, channelled in his mature years into a devotion to the fortunes of the Warwickshire County Cricket Club, and of course of the Indian National Team. He was a fine hockey player too, and gained his 'blue' at University.

Kunal was a very strong and positive personality, who had definite views and expressed them with conviction. Outgoing and extraverted in temperament, a generous nature and large of spirit, he was very definitely a social animal, had many friends and was very loyal to them. His friends found him to be a very endearing character whom they held in great affection, and whose comradeship they were proud to enjoy. Sadly, Kunal and Myra's marriage, which began in 1963, ended in divorce, but they remained very good friends over all the years. A kind and loving father, Kunal was devoted to his daughters Sima and Anjuli, and they to him.

Time and again, in the latter part of his life, Kunal battled courageously against serious illness, undergoing major surgery on several occasions, and facing all of these vicissitudes with resolution and fortitude. Those who were part of his circle grieve for the losing of him, and count themselves fortunate indeed to have shared his life's path.

\section{T.W. Fenton}

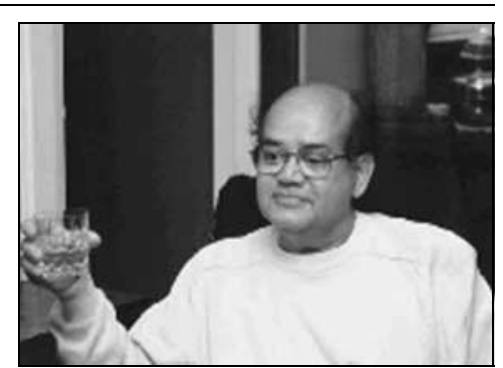

\section{Amit Bhattacharrya}

Formerly Consultant Psychotherapist, Northampton General Hospital

Amit Bhattacharrya was born in 1936 in Chandernagar, India, and graduated in 1959 MB BS in Calcutta. He had intended to train in orthopaedics in England, but sadly, he developed glaucoma, which put paid to that plan.

He switched to psychiatry and began his training at St Crispin's Hospital, Northampton in the late 1960s. In 1970, he specialised in child and family psychiatry then located at St Crispin's, where he was appointed Consultant in General Psychiatry at Kettering and at the Redcliffe Day Hospital, Wellingborough, for some years. His final appointment was as part-time Consultant in Psychotherapy at Northampton, where he remained until his retirement in May 2001.

Amit was, first and foremost, a scholar. His published work ranged widely, but his major interest was in the use of myths, particularly those originating from India, which he weaved into his own brand of psychotherapy. He wrote two chapters, edited by Kedar Dwivedi, on The Therapeutic Use of Stories (1997, Routledge).

A further special interest of his was in the emotional effects of trauma, and this was much influenced by the work of Francine Shapiro and her treatment of post-traumatic stress disorder; he went so far as to attend her first workshop in Europe. He subsequently incorporated her techniques into his own work, resulting in his own adaptation, named Eye Movement Desensitisation and Reprocessing (EMDR). His enthusiasm was such that he established an annual summer workshop/ conference held at St Andrew's Hospital, which he chaired.

Amit was an inspired teacher and a fine friend. He was very happily married for over 28 years to Christine, with whom he shared a variety of interests, not excluding West Coast malt whisky!

He died on 23 January 2003.

\section{Kedar Dwived}

Jess Sever 